\title{
Island biogeography: an avenue for research in bryology
}

\author{
JAIRO PATIÑO ${ }^{1,2} \&$ ALAIN VANDERPOORTEN ${ }^{2,3}$ \\ ${ }^{I}$ Department of Botany, Ecology and Plant Physiology, University of La Laguna, C/ Astrofísico Francisco Sánchez, 38206 La Laguna, \\ Tenerife, Canary Islands, Spain. \\ इ"jpatino@ull.edu.es; ="jpatino.llorente@gmail.com; @ https://orcid.org/0000-0001-5532-166X \\ ${ }^{2}$ Centre for Ecology, Evolution and Environmental Changes (cE3c)/Azorean Biodiversity Group, University of the Azores, Angra do \\ Heroísmo and Ponta Delgada, Azores, Portugal \\ ${ }^{3}$ Institute of Botany, University of Liège, Liège, Belgium. \\ ="a.vanderpoorten@uliege.be; @i https://orcid.org/0000-0002-5918-7709
}

\begin{abstract}
In the present review, we provide an updated account on the level of knowledge in island bryophyte biogeography. In the framework of the 50 most fundamental questions for present and future island biology research highlighted by Patiño et al. (2017), we summarize current knowledge in bryophyte island biogeography and outline main research avenues for the future in the field. We found that only about $50 \%$ of the key current questions in island biogeography have been addressed to some extent, at least once, in bryophytes. Even fundamental questions that have caught the attention of ecologists since more than one century, such as the species-area relationship, have only rarely been dealt with in bryophytes. The application of the Island Biogeography Theory therefore opens an avenue for research in bryology, and we discuss the most salient features, including species and community phylogenetics, biotic interactions, and invasion biology.
\end{abstract}

\section{Introduction}

In 1967, Robert H. MacArthur and Edward O. Wilson published their seminal work entitled the Theory of Island Biogeography (see also MacArthur \& Wilson 1963): a general mathematical theory to explain the regulation of species richness on islands. Based on the argument that island biotas eventually reach a dynamic equilibrium between processes that add species, particularly by immigration (plus, for more remote islands, speciation; MacArthur \& Wilson 1963), counterbalanced by processes that cause local extinction of species. Inspired by former literature on two main patterns in biogeography, the species - area and species — distance relationships, MacArthur \& Wilson $(1963,1967)$ decisively contributed to establish the view of islands as ideal models in ecology and evolution.

Here, we aim at assessing our state of knowledge in the field of island biogeography in bryology. In the framework of the 50 most fundamental questions for present and future island biology research foci identified by Patiño et al. (2017), we discuss how much we know and what are the most promising research arenas in island bryophyte biogeography. We focused on questions that have been addressed in bryophytes and identify, on the basis of the remaining, un-addressed questions, which topics may have been overlooked and deserve attention for future research.

\section{Methods}

We performed a literature search with Scopus, using 'island' and 'bryophyte' as keywords to obtain a first list of 716 papers. Except for specific questions such as habitat islands, we focused on oceanic islands, i.e. islands of volcanic origin, and therefore, we excluded continental islands or continental fragments (sensu Whitakker \& Fernádenz-Palacios, 2007). We further excluded articles that take place on islands but do not address biogeographic questions, such as purely floristic or taxonomic papers. In addition, we selected papers only published after the year 2000 (inclusive) to provide an account on relatively recent bryological contributions to the field. We ended-up with 52 papers, which form the basis of the present review. The questions highlighted in the subsequent sections and their order are reproduced from Patiño et al. (2017). 


\section{Island (Macro)Ecology and Biogeography}

\section{Global diversity patterns}

Q1 What are the relative roles of spatial, historical and ecological processes in driving taxonomic, phylogenetic and functional diversity patterns of insular systems?

Q2. How do fundamental biogeographic processes interact through time and space to establish the island species—area relationship?

Q3. How do taxonomic, phylogenetic and functional diversity compare between islands and ecologically similar continental areas?

Q4. How important are islands as refuges for now extinct mainland lineages and/or ecosystems?

Q5. How important are oceanic islands as generators of biodiversity and for the assembly of continental biota through reverse-colonization and/or colonization de novo?

Due to their geographic isolation, volcanic origin and elevation range, oceanic islands offer an ideal setting for disentangle the contribution of environmental and historical factors to diversity patterns (Q1). In bryophytes, a humpshape relationship between alpha diversity and elevation has been consistently reported (Henriques et al. 2017a, Boch et al. 2019, Hernández-Hernández et al. 2019, Marline et al. 2020) and interpreted in terms of the optimal climatic conditions that prevail at mid-elevation for bryophytes. Among other components of diversity, functional diversity has increasingly appeared as a complementary metric to taxonomic diversity (Spitale 2016, Øien et al. 2018, Berdugo \& Dovciak 2019). In oceanic islands, functional diversity correlates with elevation (Henriques et al. 2017a). This relationship differs, however, among communities. In Réunion island, functional richness decreases with elevation in epiphytes, but not in ground-dwelling communities, suggesting that the latter exhibit similar functional traits across the elevational gradient and may hence be more robust than epiphytic communities to disturbance (Ah-Peng et al. 2014). Phylogenetic diversity of bryophyte communities, in turn, has been to date the focus of a single study (Shaw et al. 2005), with no applications in island settings (Qs1, 3).

On oceanic islands, the Global Dynamic Model predicts that species richness is a hump-shape function of island age (Whittaker et al. 2008). While an increasing number of colonists is expected with time, the carrying capacity and environmental heterogeneity vary depending on the stage of ontogenetic phase during the typical oceanic island life cycle (Whittaker et al. 2008). Pócs (2006) noticed that habitat heterogeneity rather than island age per se determines bryophyte species richness and composition (Q1-2). Subsequent studies confirmed that alpha (Sundberg et al. 2006, Patiño et al. 2013a, Aranda et al. 2014, Tiselius et al. 2019, Torre et al. 2019, Yu et al. 2019a, b) and beta (Liu et al. 2020) diversity patterns are better explained by ecological drivers of habitat heterogeneity (area and elevation) than historical factors such as time and geographic isolation that mostly reflect dispersal limitations. These results support the idea that even parsimonious models such as the species-area relationship should sometimes be preferred as more parsimonious options as compared to more complex models when describing species richness patterns (Carey et al. 2020).

The low contribution of historical factors accounting for dispersal limitations and speciation rates is in line with the shape of the species-area relationship in bryophytes. In particular, the lower z-values of the species-area relationship in bryophytes, particularly in mosses, than in spermatophytes reflects larger range size and lower compositional turnover due to high dispersal capacities (Patiño et al. 2014b). Yu et al. (2020) further reported a shift of the slope of the speciesarea relationship beyond the Small Island Effect, which was in fact interpreted in terms of the successful filling of suitable habitats thanks to efficient colonization from mainland sources.

The limited contribution of historical factors for explaining species richness patterns contrasts with the major contribution of time in the General Dynamic Model of Island Biogeography in other organisms (Whittaker et al. 2008). This discrepancy can be explained by the fact that, in bryophytes, (i) geographic isolation filters play a limited role in bryophyte community assembly over geological times and (ii) in-situ speciation contributes much less to species richness than dispersal, which is characterized by the virtual absence of radiations (Patiño et al. 2014a).

Despite the long-distance dispersal capacities of bryophytes, disharmony, i.e., differences in species composition between island and continental biota due to factors such as geographic isolation and species dispersal capacities (Q3, König et al. 2021), has also been reported among insular bryophyte floras (Pócs 2006, Vanderpoorten et al. 2007). In line with the low contribution of historical factors for explaining bryophyte distribution patterns on islands, Vanderpoorten et al. (2007) primarily interpreted such as disharmony in terms of the lack of important habitats for 
bryophytes, such as limestone outcrops, in the investigated island. Pócs (2006), however, highlighted the potential role of random long-distance dispersal. While the hypothesis of a long-distance dispersal filter cannot be ruled-out, its relevance for explaining species richness patterns in island bryophytes is marginal as in fact, bryophyte island floras are not poorer, and sometimes richer, than continental ones (Ah-Peng et al. 2012, Patiño et al. 2015a). This pattern sharply contrasts with the expectations of the island theory. Patiño et al. (2015a) proposed that the apparent higher carrying capacities on islands result from their globally wetter, colder climates potentially more favourable to bryophytes as compared to continental regions (Weigelt et al. 2013). In turn, the high long-distance dispersal capacities of bryophytes, coupled with the typically buffered island climates and larger carrying capacities of islands during Pleistocene glacial periods (Fernández-Palacios et al. 2015), account for the substantial role of oceanic islands as: (i) a refugium (Q4-5), as evidenced by striking examples of palaeo-endemism such as Alophosia azorica (Renauld \& Cardot) Cardot and Rhynchostegiella azorica Hedenäs \& Vanderp. in the Azores (Bell \& Hyvönen 2010, Patiño \& Vanderpoorten 2015) or Hedenasiastrum percurrens (Hedenäs) Ignatov \& Vanderp. in Madeira (Aigoin et al. 2009); and (ii) a source of biodiversity for continental floras that have been dramatically affected during the Ice Ages (Hutsemékers et al. 2011, Patiño et al. 2015b, but see Stenøien et al. 2014). The role of oceanic islands as a source of de novo biodiversity for continental regions is unparalleled in any other land plant group (Patiño \& Vanderpoorten 2018). As a result, and although bryophytes may speciate at the same rates as angiosperms (Wall 2005), the rates of island endemism in bryophytes are strikingly low (Patiño \& Vanderpoorten 2018, Gradstein \& Bernard 2020) due to the fast rates of continental colonization following endemic speciation.

\section{Island ontogeny and past climate change}

Q6. How do rates of colonization, speciation and extinction change during island ontogeny?

Q7. How do diversification rates of island lineages change with island age?

Q8. How important were past geological events and climate change in promoting island colonization and altering dispersal pathways?

Q9. How has climate change influenced speciation and extinction within islands?

While, as emphasized in response to Q4 and Q5, an increase of effective insular population size and dispersal rates from islands to continents during glacial periods of the Pleistocene is supported by phylogeographic reconstructions of the historical demography of island bryophytes (Hutsemékers et al. 2011, Patiño et al. 2015b), analyses of diversification and extinction rates on islands through time (Q6-7), as well as within-island diversification analyses (Q9), are currently completely lacking for bryophytes, probably, in part, because island bryophytes typically do not radiate (Patiño et al. 2014a).

\section{Island rules and syndromes}

Q10. Is trait evolution fundamentally different on islands than on continents?

Q11. How robust are the various island rules and syndromes relating to body size, loss of dispersal, coloration, breeding system, woodiness, and clutch size, among others?

Q12. To what extent are island populations genetically impoverished, compared to comparable mainland populations?

Unlike in organisms characterized by lower dispersal capacities, the colonization of islands and archipelagos by bryophytes typically results from multiple events and different geographic origins (Vanderpoorten et al. 2008, Hutsemékers et al. 2011, Laenen et al. 2011, Stenøien et al. 2014, Patiño et al. 2016, 2017, Hanusch et al. 2020, Rodrigues et al. 2020, but see Karlin et al. 2011). Consequently, any signature of an initial bottleneck should be quickly erased by immigration (Q10), so that levels of genetic diversity are high (Liu et al. 2014), with similar or even higher values on islands, which may have served as refugia during the Ice Age (see above), than on continents (Grundmann et al. 2007, Laenen et al. 2011, Patiño et al. 2015b). A lower genetic diversity in island than continental populations was, however, evidenced in Sphagnum palustre L. (Stenøien et al. 2014) and Rhynchostegium riparioides (Hedw.) Cardot (Q12). In the latter, and although clonal reproduction does not necessarily preclude the evolution of high levels of 
genetic diversity, as evidenced in sterile populations of Sphagnum palustre in Hawaii following a single colonization event (Karlin et al. 2011), the significantly higher linkage disequilibrium found in island populations as compared to continental ones was interpreted as a shift towards increased rates of selfing and/or clonality (Hutsemékers et al. 2011).

Such a shift in sexual strategies on islands is consistent with the increase in the proportion of species producing specialized asexual diaspores, which are assumed to play a role in short-distance dispersal, and a decrease of species producing spores, which are involved in long-distance dispersal (but see Laenen et al. 2016a), revealed by a metaanalysis of life-history traits of insular bryophyte floras and species (Patiño et al. 2013b). The pattern observed might be tentatively linked to the loss of dispersal hypothesis (Q11), a traditional island syndrome (Whittaker \& FernándezPalacios 2007, but see García-Verdugo et al. 2017, Burns 2018). Whether dispersal capacity is truly counter-selected on islands, or shifts in dispersal traits on islands occur as a response to the specificities of the island environment, and dispersal and ecological filters (Patiño et al. 2013b), remains unanswered.

\section{Island biogeography theory}

Q13. How do the dynamics of island communities scale up to generate the biogeographical patterns predicted by island biogeographical theories?

Q14. How can we reconcile island biogeography theories with other ecological and evolutionary theories to contribute to a general biodiversity theory?

Q15. How applicable are island biogeographical theories derived from real islands to other forms of insular system, such as sky islands and seamounts?

Q16. How can we best incorporate population genetic and/or phylogenetic data to advance models of island biogeography?

The Island Biogeography Theory has been applied to continental island systems in bryophytes in a few instances (Q15). In soil islands of rocky outcrops in the semi-arid region of Brazil, Silva et al. (2018) for example failed to evidence a significant species-area relationship, which they interpreted in terms of random, opportunistic colonization. Due to relative similarities between trees and oceanic islands in terms of geographic isolation and evolution of the physical properties during their respective ontogenetic development, the application of the Island Biogeography Theory in general and the General dynamic Model of Island Biogeography (Whittaker et al. 2008) in particular, has been of relevance in the case of epiphytic systems (Taylor \& Burns 2015). In bryophytes, Patiño et al. (2018) reported that tree age was consistently included in all of the best-fit models, reflecting the progressive increase in epiphyte bryophyte species richness through time. The limited contribution of the quadratic product of time and tree height to the best models suggested, however, that competition for space is not a key factor on mature trees.

\section{Island (Macro)Evolution}

\section{Immigration-speciation—extinction dynamics}

Q17. How does the spatial configuration of an archipelago (e.g. intra-archipelagic connectivity) influence colonization, speciation and extinction over time?

Q18. What is the nature of the relationship between rates of extinction and island isolation, if any?

Q19. How do the extinction probabilities of island endemic species compare to those of non-endemic species?

Q20. How important are diversity-dependent processes for island colonization, speciation and extinction?

Q21. How do anthropogenic extinctions affect estimates of speciation and natural extinction on island systems?

Estimating extinction rates largely depends on the availability of fossil records. Quaternary macrofossils are, however, typically rare in many oceanic islands, which, such as the Canary Islands, lack peat deposits and wherein lacustrine deposits, where such fossils can be found, are scarce. In addition, fossilization in bryophytes is much rarer than in vascular plants due to the lack of decay-resistant lignified tissues, complicating the use of fossil records to document extinction rates in island bryophytes. As a result, no bryophytes were recorded from the cores performed in the Azores 
(Góis-Marques et al. 2019) or Canary Islands (de Nascimento et al. 2009, Nogué et al. 2013). The recent discovery of early Pleistocene fossils in Madeira (Góis-Marques et al. 2018) opens the door to the integration of fossils into phylogenetic diversification analyses to disentangle speciation and extinction rates. Another promising avenue for research on immigration/extinction rates in island bryophytes comes from the diachronic analyses of floras of newly emerged islands. In particular, Ingimundardóttir et al. (2014) took advantage of the unique opportunity to measure rates of colonization and extinctions through the monitoring of the flora of the Surtsey island, formed by a volcanic eruption south of Iceland in 1963-1967. The number of species doubled between 1971 and 1972, with a subsequent decrease of the colonization rate of $21 \%$ and a putative extinction rate of $71 \%$ in 2008 . Further research on island bryophyte fossils and experimental assessments of demographic rates will be necessary to address the series of questions around diversification patterns (Q17-Q21), which remain almost completely un-addressed presently in bryophytes.

\section{Speciation and diversification}

Q22. What functional traits (e.g. relating to dispersal capacity, reproduction, trophic ecology) are associated with high diversification rates within and across island systems?

Q23. What traits best predict which groups will undergo adaptive radiation on islands?

Q24. What is the relative importance of ecological versus geographical speciation on islands?

Q25. What is the influence of gene flow among islands and/or between islands and mainland areas on speciation rates?

While databases of functional traits have increasingly become available for island bryophytes (e.g. Henriques et al. 2017b for Azorean bryophytes), very few analyses have been conducted to date to test the hypothesis that key innovation triggered bryophyte species diversification (Q22). Wall (2005) tentatively interpreted the diversification of the moss genus Mitthyridium H. Rob. in Pacific islands as the result of a shift in reproductive strategy from sexual to asexual, consistent with similar observations based on genetic data and analyses of life-history traits (see above), and which was proposed as a key innovation. Laenen et al. (2016b) conversely found that increases in diversification rates in liverworts are associated with shifts towards bisexuality. These contrasted findings suggest that the question of how traits can drive diversification rates and what is the importance of adaptative radiations in insular bryophyte floras in particular, requires further investigation (Q22-24).

Despite that variation of genetic diversity and similarity along elevation gradients (Pisa et al. 2015, Sim-Sim et al. 2015) suggests that island bryophytes may diversify as a response to environmental variation, they are characterized by non-radiating speciation modes within archipelagic regions (Patiño et al. 2014a) and thus do not seem to be prone to ecological diversification (Q23-24). Pócs (2006) discussed potential radiations in Caribbean Pilotrichum P. Beauv. and epiphyllous liverworts from the Indian Ocean islands, but whether these diversification patterns result from actual in-situ radiations remains to be tested, as the presence of several congeneric endemics on the same island or archipelago may not necessarily point to a monophyletic origin. This is best illustrated in the case of Macaronesian Rhynchostegiella (Schimp.) Limpr. Species, where none of the endemic Macaronesian endemic species form a clade (Patiño \& Vanderpoorten 2015).

High dispersal rates between island and continental populations (Q25) have typically been identified as the cause of the low levels of endemism in island bryophytes (Vanderpoorten et al. 2011). The lack of evidence for different regimes in diversification rates across insular and continental lineages in the moss genus Rhynchostegiella suggests, however, that diversification takes place at comparable rates in island and continental lineages. This suggests that restrictions to gene flow in insular environments may be sufficient to elevate diversification rates to levels comparable to those observed at much larger continental scales, even in organisms with high long-distance dispersal capacities such as bryophytes. Mounting evidence from fine-scale population genetic studies in bryophytes reveals a significant partitioning of genetic variation among populations structured by short geographical distances (Vanderpoorten et al. 2019). We thus propose that the minimum geographical distance required for neutral divergence, and hence speciation, might be much shorter than what bryophytes' capacity for occasional and random long-distance dispersal suggests. 


\section{Dispersal and colonization}

Q26. What is the importance of founder effects for the evolution of island lineages?

Q27. How frequent is inter-island dispersal and is it enough to form an archipelago-wide metacommunity, or are islands better understood as functionally independent communities?

Q28. How can palaeoecology contribute to the understanding of species arrival, establishment and spread on islands?

The limited number of population genetic studies in island bryophytes prevents the emergence of robust conclusions on the effects of founder events in insular bryophytes (Q26). No signature of a bottleneck was found in populations of Bryum argenteum in Tenerife, possibly because of recurrent immigrations events (Pisa et al. 2015). If this pattern is indeed recurrent, it could prevent endemic speciation due to gene flow intensity (Vanderpoorten et al. 2008, 2011) or niche pre-emption (Silvertown et al., 2005), assuming that competition could play a sufficient role to shape bryophyte communities. In the endemic Orthotrichum handiense F. Lara, Garilleti \& Mazimpaka, which is represented by a single population in a small area of the island of Fuerteventura, evidence for a recent bottleneck was found (Patiño et al. 2013c), but whether it is caused by a founder effect or subsequent local extinction events could not be determined. In Rhynchostegiella, Patiño \& Vanderpoorten (2015) documented recurrent cases of allopatric speciation in mainland areas from continental ancestors, possibly promoted by founder effects. More examples of populations genetic analyses of island bryophytes, including analyses of their connectivity among populations from different islands and how this connectivity regulates diversification rates, which are today completely lacking (Q27), would be necessary to address the question of the evolution of such insular populations, and whether disruption of gene flow among islands could, as in angiosperms (White et al. 2020), promote allopatric speciation through founder events.

\section{Island Community Ecology}

\section{Community assembly}

Q29. How do taxonomic, phylogenetic and functional diversities of island communities change during assembly and disassembly of island systems?

Q30. How do island area, elevation and isolation influence the community composition and dynamics of island systems?

Q31. What are the relative roles of island age, phylogenetic group and functional ecology in determining natural (background) extinction rates among oceanic island taxa?

Q32. How does the order of colonization influence emergent outcomes in the assembly of island biotas?

Q33. How important are rare species for the functioning of island communities?

Q34. How does in situ evolution drive the functioning of island ecosystems?

Q35. How do climate and sea-level changes influence biotic interactions on islands?

Q36. How do biotic interactions (within and between trophic levels) influence immigration, extinction and speciation rates on islands?

Questions around community assembly have seldom been addressed in bryophytes. Pócs (2006) suggested that, following chance long-distance dispersal, 'first incidental colonizers' quickly spread across suitable habitats, preventing other species to establish (Q36) and resulting in very different species compositions among islands from the same archipelago. This mechanism of niche pre-emption (sensu Silvertown et al. 2005) involves a substantial role for competition, which has been questioned in bryophytes and should be further tested (see below).

\section{Island Conservation and Management}

\section{Global change}

Q37. How, if at all, do island biotas differ from continental biotas in their response to global change?

Q38. Are island species more prone to extinction than their closest relatives on the mainland, and if so, why? 
Q39. How can we identify which island taxa are most at risk from global change and what are their risk-associated traits?

Q40. What determines anthropogenic extinction rates among island taxa?

Q41. How do anthropogenic changes within islands impact on the capacity of island species to respond successfully to climate change?

Q42. How can we identify islands that are more susceptible to biodiversity loss in the coming decade, and what are the most efficient and cost-effective methods (i.e. policy; education; research; management) for safeguarding their biodiversity?

Q43. What are the best strategies for in situ conservation of island species impacted by non-native species?

Q44. What are the most effective methods for responding to the anthropogenic extinction crisis on islands?

Q45. How can we best implement long-term monitoring schemes on islands to provide quantitative evidence of changes within island ecological systems?

Q46. How can conservation interests best be integrated with other island stakeholder interests (particularly tourism) on populated islands?

Q47. What are the impacts of novel biotic interactions between and among alien and native species on island biodiversity and ecosystem functioning?

Q48. How does the invasion stage (i.e. colonization, establishment, and long-term adaptation) of alien taxa affect distribution ranges and biotic interactions of native insular biotas?

Q49. To what extent can alien species act as functional substitutes for extinct native species on islands?

Q50. How do the ecological effects of introduced species differ from those of naturally arriving colonist species on islands?

The proportion of threatened (sensu IUCN) species in the Canary Islands and Madeira, which reaches 21 and 23\%, respectively (Gonzalez-Mancebo et al. 2012, Sim-Sim et al. 2014), lays within the range reported for European bryophytes in general (Hodgetts et al. 2019). This does not suggest, at first sight, that island species are more prone to extinction than their closest relatives in the mainland (Q38). However, comparisons of altitudinal ranges of species in Réunion island with those of continental mountain ranges revealed that the former are narrower than the latter (Ah-Peng et al. 2012). Furthermore, projections of species distribution models for Macaronesian endemic species onto future climatic layers pointed to an average decrease of suitable areas of $62-87 \%$ per species (Patiño et al. 2016), which is comparatively higher than the $16-42 \%$ of range loss predicted for the European bryophyte flora (Zanatta et al. 2020). Model predictions suggest that even the commonest endemic species would fit either the Vulnerable or Endangered IUCN categories by 2070 (Patiño et al. 2016). The predicted extinction of approximately $17.1 \%$ of the Macaronesian endemic bryophyte species by 2070 is also higher than the average of $7.9 \%$ of extinction due to climate change when different taxa (including birds, reptiles, amphibians, invertebrates, mammals, fish and plants) worldwide (Patiño et al. 2016). These results suggest that island endemic bryophytes will be among the first to disappear in a warmer world, thus at faster rates than continental species (Q37-38). Model predictions further point to substantial differences in terms of extinction risks among archipelagos (Q42). Thus, predictions for the decrease of the macroclimatically suitable area of the Macaronesian endemic bryoflora by 2070 are substantially more severe in the Canary Islands (77-96\% on average depending on the investigate climate change scenarios) than in the Azores (55.2-80.5\%) and Madeira (50-79.3\%) (Patiño et al. 2016).

The links between species traits important for dispersal and competition on the one hand, and occurrences on the other (Virtanen 2014), provide baseline information for assessing species rarity (Söderström \& During 2005) and threat levels (Bergamini et al. 2019), and hence, identify which taxa are most at risk from global change (Q39). In oceanic island bryophytes, risks of extinction in fact correlate with life-history strategies (Lloret \& González-Mancebo 2011). In particular, the shifts towards increased rates of asexual reproduction (Patiño et al. 2013b), further illustrated by the apparently purely clonal reproduction of island populations reported in some instances (Karlin et al. 2011), along with evidence for strong intra-island genetic structures (Liu et al. 2014), suggest at first sight that island species are prone to extinction due to decreased dispersal capacities. The idea that island species exhibit lower dispersal capacities than continental ones has, however, been challenged by estimates of migration rates derived from analyses of spatial genetic structures (Hutsemékers et al. 2011).

Long-term monitoring schemes (Q45), including bryophytes, have been launched in the framework of the main projects, namely BRYOLAT (Réunion, Comoros, and Madagascar) and Moveclim (MOntane VEgetation as listening posts for CLIMate change in Pico (Azores), La Palma (Canary Islands), Guadeloupe, Réunion, and Tahiti) to provide quantitative baselines for detecting changes within island ecosystems and evaluate the effectiveness of conservation 
and management actions (Henriques et al. 2016; Hernández-Hernández et al. 2018). Permanent plots were established every $200 \mathrm{~m}$ along the elevational gradient following the protocol described by Ah-Peng et al. (2012) and later included in the Global Island Monitoring Scheme for the long-term coordinated survey and monitoring of native island biota (Borges et al. 2018).

The impact of alien species, both spermatophytes and bryophytes, on the native bryophyte flora $(\mathrm{Q} 47,49)$ has only quite recently been investigated. Marignani et al. (2019) for instance reported a low but significant negative influence of the introduced Carpobrotus N.E. Br. on bryophyte species richness and functional diversity of degraded sandy seashores in Sardinia. Alien trees may, however, serve as a substitutive habitat for epiphytes. In the Azores for instance, reduced substratum specificity (Gabriel \& Bates 2005) and, in particular, tree host-specificity, results in rich epiphytic assemblages on alien trees. On islands with extremely severe loss of native vegetation such as in Cape Verde, alien trees may even represent the only available habitat for the native epiphytic flora (Gonzalez-Mancebo et al. 2009). While plantations may hence contribute to the conservation of the native bryophyte flora, on islands but also in continental environments (Kautz \& Gradstein 2001), their impact in insular forest ecosystems requires further research.

\section{Synthesis and discussion}

Island biogeography has been an increasing focus in bryology fueled, among others, by the increasing availability of checklists, whose comparisons have been possible thanks to standardized species lists worldwide, large-scale environmental databases, phylogenies and associated bioinformatic tools, and species trait databases. Still, many key areas in the field remain largely unexplored by bryologists, and we discuss the most salient features hereafter.

Phylogenetic diversity, a measure of the average branch length among species from a community, which has been largely employed in ecology, evolutionary and conservation biology (Miller et al. 2017) and highlighted as a crucial addition to advance models of island biogeography (Patiño et al. 2017), has been the focus of a single paper in bryophytes (Shaw et al. 2005), with no application to islands. Other phylogenetic community structure metrics (Miller et al. 2017) have not been applied at all. In particular, phylogenetic turnover can serve as a mean to disentangle the contribution of selective (habitat specialization) and neutral factors (dispersal limitations) on the spatio-temporal evolution of biodiversity patterns (Saladin et al. 2019), and its application to island bryophyte communities would open the door to novel studies on key issues in ecology, such as niche conservatism.

Such studies are currently impeded by two major shortcomings: (i) the lack of species distribution data; and (ii) the lack of robust and well-sampled species-level phylogenies. The first issue primarily requires a standardized checklist of accepted species names, with a list of synonyms. While such a list is now available for liverworts (Söderström et al. 2016), the lack of a similar work for mosses is a major impediment to any macroecological and macroevolutionary analysis in the group. Secondarily, checklists of species per island are required. In bryophytes, species lists have most recently become available for islands as Ascension (Pressel et al. 2017) or Fernando de Noronha (da Costa et al. 2018), but such basic information is largely missing, not updated or incomplete for many archipelagos (e.g. Hawaii, French Polynesia, Juan Fernández).

The second issue calls for the launching of a large, collaborative project to reconstruct the Moss and Liverwort Trees of Life. Earlier backbone phylogenies for mosses and liverworts (Cox et al. 2010, Laenen et al. 2014) date back to the Sanger sequencing era, and were hence based on a relatively limited number of loci (three and eight, respectively). As the number of taxa will progressively become much larger than the number of variable sites as new species are added, re-analyzing the same data with increasing numbers of Operational Taxonomic Units will likely result in increasingly poorly supported trees. Next-generation sequencing techniques open the door to the production of massive amount of data at comparatively low cost. In mosses, a backbone phylogeny was produced (Liu et al. 2019) based on a protocol of gene capture, subsequently further developed to target over 600 unicopy nuclear loci and their flanking, non-coding regions, potentially offering suitable levels of variation at the species and infraspecific levels (Medina et al. 2019). Such a large number of loci would allow the use of Liu's et al. (2019) phylogenetic hypothesis as a backbone to subsequently add new OTUs and progressively build a species-level Moss Tree of Life. A similar protocol could be applied to liverworts in order to generate well-sampled phylogenies at the taxonomic and molecular levels.

Biotic interactions are a key issue in island biogeography (see Q35-36, 46 and 48). In fact, competition forms the basis of the niche pre-emption hypothesis proposed by Silvertown et al. (2005) and applied to bryophytes (Pócs 2006), 
according to which colonization rates, and, ultimately, chances of endemic speciation, are controlled by competition. The importance of biotic interactions for shaping bryophyte communities has, however, been debated (see Patiño \& Vanderpoorten 2018 for review). Mounting concerns about methods based on co-occurrence analyses (Blanchet et al. 2020) unfortunately render the analysis of such interactions very challenging and call for integrative approaches based on a combination of environmental, spatial and quantitative trait data in order to disentangle the nature of species associations.

The issue of biotic interactions is especially of prime importance in oceanic islands due to the sensitivity of the latter to biological invasions (Q47-50). In the case of bryophytes, Essl et al. $(2013,2015)$ were the first to provide a comprehensive assessment of the environmental and anthropogenic factors driving bryophyte invasions worldwide. They found that alien bryophyte species occurrences are more frequent on islands and depend on native range size, and hence probably propagule pressure, and that naturalized bryophytes are more frequent in areas which are biogeographically separated but climatically similar to the native ranges. As Söderström (1992) earlier noticed, however, assessing the native or introduced origin of bryophytes species is extremely challenging. Essl et al. $(2013,2015)$ used criteria such as anomalous geographical distribution, preference for disturbed habitats, and indirect associations with some means of human transport as criteria to identify aliens. Because bryophytes exhibit high long-distance dispersal capabilities, and because native species may experience striking expansion phases, mimicking invasions (Hassel et al. 2005), the reliability of such criteria based on distribution patterns can be questioned (Vanderpoorten \& Patiño 2015). In this case, a time-consuming, but more reliable way to assess the native or introduced status of a bryophyte species, as exemplified by the case of the weedy Bryum argenteum Hedw. in Tenerife (Pisa et al. 2015), involves the characterization of the genetic structure, as a (recently) introduced species is expected to exhibit signs of a bottleneck associated with the founding event and no pattern of isolation-by-distance or in-situ diversification.

Finally, our review reveals that only about $50 \%$ of the key current questions in island biogeography (Patiño et al. 2017) have been addressed, at least once, in bryophytes. As a matter of fact, and as Yu et al. (2020) emphasized, even fundamental questions that have caught the attention of ecologists since more than one century, such as the speciesarea relationship, have only rarely been dealt with in bryophytes. The application of the Island Biogeography Theory therefore opens an avenue for research in bryology.

\section{Acknowledgements}

Many thanks are due to Claudine Ah-Peng and an anonymous reviewer for their constructive comments on the manuscript. J.P. was funded by the Ministerio de Ciencia e Innovación (MICINN) through the Ramón y Cajal program (RYC-2016-20506). This research was partially supported by the Fundación BBVA project (INVASION - PR19_ ECO_0046) and MICINN project (ASTERALIEN - PID2019-110538GA-I00).

\section{References}

Ah-Peng, C., Wilding, N., Kluge, J., Descamps-Julien, B., Bardat, J., Chuah-Petiot, M., Strasberg, D. \& Hedderson, T. (2012) Bryophyte diversity and range size distribution along two altitudinal gradients: continent vs. island. Acta Oecologica 42: 58-65. https://doi.org/10.1016/j.actao.2012.04.010

Ah-Peng, C., Flores, O., Wilding, N., Bardat, J., Marline, L., Hedderson, T.A.J. \& Strasberg D. (2014) Functional diversity of subalpine bryophyte communities in an oceanic island (La Réunion). Arctic, Antarctic, and Alpine Research 46: 841-851. https://doi.org/10.1657/1938-4246-46.4.841

Aigoin, D., Ignatov, M.S., Huttunen, S., Devos, N., Gonzalez-Mancebo, J.M. \& Vanderpoorten, A. (2009) And if Engler was not completely wrong? Evidence for multiple origins in the moss flora of Macaronesia. Evolution 63: 3248-3257. https://doi.org/10.1111/j.1558-5646.2009.00787.x

Aranda, S.C., Gabriel, R., Borges, P.A.V., Santos, A.M.C., De Azevedo, E.B, Patiño, J., Hortal, J. \& Lobo, J.M. (2014) Geographical, temporal and environmental determinants of bryophyte species richness in the Macaronesian Islands. PLoS ONE 9: e101786. https://doi.org/10.1371/journal.pone.0101786

Blanchet, F.G., Cazelles, K. \& Gravel, D. (2020) Co-occurrence is not evidence of ecological interactions. Ecology Letters 23: 10501063.

https://doi.org/10.1111/ele.13525 
Borges, P.A.V., Cardoso, P., Kreft, H., Whittaker, R.J., Fattorini, S., Emerson, B.C., Gil, A., Gillespie, R.G., Matthews, T.J., Santos, A.M.C., Steinbauer, M.J., Thébaud, C., Ah-Peng, C., Amorim, I.R., Calvo Aranda, S., Moura Arroz, A., Azevedo, J.M., Boieiro, M., Borda-de-Água, L., Carvalho, J.C., Elias, R.B., Fernández-Palacios, J.M., Florencio, M., González-Mancebo, J.M., Heaney, L.R., Hortal, J., Kueffer, C. Lequette, B., Martín-Esquivel, J.M., López, H., Lamelas-López, L., Marcelino, J., Nunes, R., Oromí, P., Patiño, J. Pérez, A.J., Rego, C., Ribeiro, S.P., Rigal, F., Rodrigues, P., Rominger, A.J., Santos-Reis, M., Schaefer, H., Sérgio, C., Serrano, A.R.M., Sim-Sim, M., Stephenson, P.J., Soares, A.O., Strasberg, D., Vanderporten, A., Vieira, V. \& Gabriel, R. (2018) A Global Island Monitoring Scheme (GIMS) for the long-term coordinated survey and monitoring of native island forest biota. Biodiversity and Conservation 27: 2567-2586. https://doi.org/10.1007/s10531-018-1553-7

Borregaard, M.K., Amorim, I.R., Borges, P.A.V., Cabral, J.S., Fernández-Palacios, J.M., Field, R., Heaney, L.R., Kreft, H., Matthews, T.J., Olesen, J.M., Price, J., Rigal, F., Steinbauer, M.J., Triantis, K.A., Valente, L., Weigelt, P. \& Whittaker, R.J. (2016) Oceanic island biogeography through the lens of the general dynamic model: assessment and prospect. Biological Reviews 92: 830-853. https://doi.org/10.1111/brv.12256

Bell, N.E. \& Hyvönen, J. (2010) Phylogeny of the moss class Polytrichopsida (Bryophyta): Generic-level structure and incongruent gene trees. Molecular Phylogenetics and Evolution 55: 381-398.

https://doi.org/10.1016/j.ympev.2010.02.004

Berdugo, M.B. \& Dovciak, M. (2019) Bryophytes in fir waves: Forest canopy indicator species and functional diversity decline in canopy gaps. Journal of Vegetation Science 30: 235-246.

https://doi.org/10.1111/jvs.12718

Bergamini, A., Bisang, I., Hodgetts, N., Lockhart, N., van Rooy, J. \& Hallingbäck, T. (2019) Recommendations for the use of critical terms when applying IUCN red-listing criteria to bryophytes. Lindbergia 2019: 1-6. https://doi.org/10.25227/linbg.01117

Boch, S., Martins, A., Ruas, S., Fontinha, S., Carvalho, P., Reis, F., Bergamini, A. \& Sim-Sim, M. (2019) Bryophyte and macrolichen diversity show contrasting elevation relationships and are negatively affected by disturbances in laurel forests of Madeira island. Journal of Vegetation Science 30: 1122-1133. https://doi.org/10.1111/jvs. 12802

Burns, K. (2018) Time to abandon the loss of dispersal ability hypothesis in island plants: A comment on García-Verdugo, Mairal, Monroy, Sajeva and Caujapé-Castells (2017). Journal of Biogeography 45: 1219-1222. https://doi.org/10.1111/jbi.13223

Carey, M., Boland, J., Weigelt, P. \& Keppel, G. (2020) Towards an extended framework for the general dynamic theory of biogeography. Journal of Biogeography 47: 2554-2566. https://doi.org/10.1111/jbi.13944

Cox, C. J., Goffinet, B., Wickett, N.J., Boles, S.B. \& Shaw, A.J. (2010) Moss diversity: a molecular phylogenetic analysis of genera. Phytotaxa 9: 175-195.

https://doi.org/10.11646/phytotaxa.9.1.10

Da Costa, D.P., Henriques, D.K., Carvalho Silva, M., Duckett, J. \& Pressel, S. (2018) Bryophytes on Fernando de Noronha island, South Atlantic. Field Bryology 120: 38-48.

de Nascimento, L., Willis, K., Fernández-Palacios, J.M., Criado, C. \& Whittaker, R. (2009). The long-term ecology of the lost forests of La Laguna, Tenerife (Canary Islands). Journal of Biogeography 36: 499-514. https://doi.org/10.1111/j.1365-2699.2008.02012.x

Essl, F., Steinbauer, K., Dullinger, S., Mang, T. \& Moser, D. (2013) Telling a different story: a global assessment of bryophyte invasions. Biological Invasions 15: 1933-1946. https://doi.org/10.1007/s10530-013-0422-2

Essl, F., Dullinger, S., Moser, D., Steinbauer, K. \& Mang, T. (2015) Macroecology of global bryophyte invasions at different invasion stages. Ecography 37: 1-11. https://doi.org/10.1111/ecog.00905

Fernández-Palacios, J.M., Kueffer, C. \& Drake, D. (2015) A new golden era in island biogeography. Frontiers of Biogeography 7: 1420. https://doi.org/10.21425/F57124493

Gabriel, R. \& Bates, J.W. (2005) Bryophyte community composition and habitat specificity in the natural forests of Terceira, Azores. Plant Ecology 177:125-144. https://doi.org/10.1007/s11258-005-2243-6

García-Verdugo, C., Mairal, M., Monroy, P., Sajeva, M. \& Caujapé-Castells, J. (2017) The loss of dispersal on islands hypothesis revisited: Implementing phylogeography to investigate evolution of dispersal traits in Periploca (Apocynaceae). Journal of Biogeography 44: 
2595-2606.

https://doi.org/10.1111/jbi.13050

Góis-Marques, C.A., de Nascimento, L., Sequeira, M., Fernández-Palacios, J.M. \& Madeira, J. (2018). The first record of Bryophyta macrofossils from the Early Pleistocene of Madeira Island (Portugal). Proceedings of the FloraMac 2018 conference, Funchal (Madeira): 65.

Góis-Marques, C.A., de Nascimento, L., Sequeira, M., Fernández-Palacios, J.M. \& Madeira, J. (2019). The Quaternary plant fossil record from the volcanic Azores Archipelago (Portugal, North Atlantic Ocean): a review. Historical Biology 31: 1267-1283. https://doi.org/10.1080/08912963.2018.1444761

González-Mancebo, J.M., Draper, I., Lara, F., Marrero, J.D., Munoz, J., Patiño, J., Romaguera, F. \& Vanderpoorten, A. (2009) Amendments to the bryophyte flora of the Cape Verde and Canary Islands. Cryptogamie, Bryologie 30: 433-441.

González-Mancebo, J.M., Dirkse, G.M., Patiño, J., Romaguera, F., Werner, O., Ros, R.M. \& Martín, J.L. (2012) Applying the IUCN Red List criteria to small-sized plants on oceanic islands: Conservation implications for threatened bryophytes in the Canary Islands. Biodiversity and Conservation 21: 3613-3636. https://doi.org/10.1007/s10531-012-0385-0

Gradstein, S.R. \& Bernard, E.L. (2020) An evaluation of the endemic bryophyte flora of Guadeloupe. Cryptogamie, Bryologie 41: 205214. https://doi.org/10.5252/cryptogamie-bryologie2020v41a15

Grundmann, M., Ansell, S.W., Russell, S.J., Koch, M.A. \& Vogel, J.C. (2007) Genetic structure of the widespread and common Mediterranean bryophyte Pleurochaete squarrosa (Brid.) Lindb. (Pottiaceae)-Evidence from nuclear and plastidic DNA sequence variation and allozymes. Molecular Ecology 16: 709-722. https://doi.org/10.1111/j.1365-294X.2007.03181.x

Hanush, M., Ortiz, E.M., Patiño, J. \& Schafer, H. (2020) Biogeography and integrative taxonomy of Epipterygium (Mniaceae, Bryophyta). Taxon. [in press] https://doi.org/10.1002/tax.12324

Hassel, K., Såstad, S.M., Gunnarsson, U. \& Söderström, L. (2005) Genetic variation and structure in the expanding moss Pogonatum dentatum in its area of origin and in a recently colonised area. American Journal of Botany 92: 1684-1690. https://doi.org/10.3732/ajb.92.10.1684

Henriques, D.S.G., Borges, P.A.V., Ah-Peng, C. \& Gabriel, R. (2016) Mosses and liverworts show contrasting elevational distribution patterns in an oceanic island (Terceira, Azores): the influence of climate and space. Journal of Bryology 38: $183-194$. https://doi.org/10.1080/03736687.2016.1156360

Henriques, D.S.G., Borges, P.A.V. \& Gabriel, R. (2017a) Regional processes drive bryophyte diversity and community composition in a small oceanic island. Community Ecology 18: 193-202. https://doi.org/10.1556/168.2017.18.2.9

Henriques, D.S.G., Ah-Peng, C., Gabriel, R. (2017b) Structure and applications of BRYOTRAIT-AZO, a trait database for Azorean bryophytes. Cryptogamie, Bryologie 38: 137-152. https://doi.org/10.7872/cryb/v38.iss2.2017.137

Hernández-Hernández, R., Borges, P.A.V., Gabriel, R., Rigal, F., Ah-Peng C. \& González-Mancebo, J.M. (2017) Scaling $\alpha$ - and $\beta$-diversity: bryophytes along an elevational gradient on a subtropical oceanic Island (La Palma, Canary Islands). Journal of Vegetation Science 28: $1209-1219$. https://doi.org/10.1111/jvs.12573

Hernández-Hernández, R., Kluge, J., Ah-Peng, C. \& González-Mancebo, J.M. (2019) Natural and human-impacted diversity of bryophytes along an elevational gradient on an oceanic island (La Palma, Canarias). PLoS ONE 14: e213823. https://doi.org/10.1371/journal.pone.0213823

Hodgetts, N., Cálix, M., Englefield, E., Fettes, N., García Criado, M., Patin, L., Nieto, A., Bergamini, A., Bisang, I., Baisheva, E., Campisi, P., Cogoni, A., Hallingbäck, T.,Konstantinova, N., Lockhart, N., Sabovljevic, M., Schnyder, N., Schröck, C., Sérgio, C., Sim Sim, M., Vrba, J., Ferreira, C.C., Afonina, O., Blockeel, T., Blom, H., Caspari, S., Gabriel, R., Garcia, C., Garilleti, R., González Mancebo, J., Goldberg, I., Hedenäs, L., Holyoak, D., Hugonnot, V., Huttunen, S., Ignatov, M., Ignatova, E., Infante, M., Juutinen, R., Kiebacher, T., Köckinger, H., Kučera, J., Lönnell, N., Luth, M., Martins, A., Maslovsky, O., Papp, B., Porley, R., Rothero, G., Söderström, L., Ştefănuţ, S., Syrjänen, K., Untereiner, A., Váňa, J. I, Vanderpoorten, A., Vellak, K., Aleffi, M., Bates, J., Bell, N., Brugués, M., Cronberg, N., Denyer, J., Duckett, J., During, H.J., Enroth, J., Fedosov, V., Flatberg, K.-I., Ganeva, A., Gorski, P., Gunnarsson, U., Hassel, K., Hespanhol, H., Hill, M., Hodd, R., Hylander, K., Ingerpuu, N., Laaka-Lindberg, S., Lara, F., Mazimpaka, V., Mežaka, A., Muiller, F., Orgaz, J.D., Patiño, J., Pilkington, S., Puche, F., Ros, R.M., Rumsey, F., Segarra-Moragues, J.G., Seneca, A., Stebel, A., Virtanen, R., Weibull, H., Wilbraham, J. \& Żarnowiec, J. (2019) A miniature world in decline: European Red List of Mosses, Liverworts and Hornworts. Brussels, Belgium: IUCN. 
Hutsemekers, V., Shaw, A.J., Szvövenyi, P., Gonzalez-Mancebo, J.M., Munoz, J. \& Vanderpoorten, A. (2011) Islands are not sinks of biodiversity in spore-producing plants. Proceedings of the National Academy of Sciences of the USA 108: 18989-18994.

https://doi.org/10.1073/pnas.1109119108

Ingimundardóttir, G.V., Weibull, H. \& Cronberg, N. (2014) Bryophyte colonization history of the virgin volcanic Island Surtsey, Iceland. Biogeosciences 11: 4415-4427.

https://doi.org/10.5194/bg-11-4415-2014

Karlin, E.F., Hotchkiss, S.C., Boles, S.B., Stenøien, H.K., Hassel, K., Flatberg, K.I. \& Shaw, A.J. (2012) High genetic diversity in a remote island population system: Sans sex. New Phytologist 193: 1088-1097. https://doi.org/10.1111/j.1469-8137.2011.03999.x

Kautz, T. \& Gradstein, S.R. (2001) On the ecology and conservation of Spruceanthus theobromae (Lejeuneaceae, Hepaticae) from Western Ecuador. The Bryologist 104: 607-612; https://doi.org/10.1639/0007-2745(2001)104[0607:OTEACO]2.0.CO;2

König, C., Weigelt, P., Taylor, A., Stein, A., Dawson, W., Essl, F., Pergl, J., Pyšek, P., van Kleunen, M., Winter, M., Chatelain, C., Wieringa, J.J., Krestov, P. \& Kreft, H. (2021) Source pools and disharmony of the world's island floras. Ecography 44: 44-55. https://doi.org/10.1111/ecog.05174

Laenen, B., Désamoré, A., Devos, N., Shaw, A.J., Carine M.A., Gonzalez-Mancebo J.M. \& Vanderpoorten A. (2011) Macaronesia: a source of hidden genetic diversity for post-glacial recolonization of western Europe in the leafy liverwort Radula lindenbergiana. Journal of Biogeography 38: 631-639. https://doi.org/10.1111/j.1365-2699.2010.02440.x

Laenen, B., Shaw, B., Schneider, H., Goffinet, B., Paradis, E., Désamoré, A., Heinrichs, J., Villarreal, J.C., Gradstein, S.R., McDaniel, S.F., Long, D.G., Forrest, L., Hollingsworth, M., Crandall-Stotler, B., Davis, E.C., Engel, J., Von Konrat, M., Cooper, E.D., Patiño, J., Vanderpoorten, A. \& Shaw, A.J. (2014) Extant diversity of bryophytes emerged from successive post-Mesozoic diversification bursts. Nature Communications 5: 5134. https://doi.org/10.1038/ncomms6134

Laenen, B., Machac, A., Gradstein, S.R., Shaw, B., Patiño, J., Désamoré, A., Goffinet, B., Cox, C.J., Shaw, A.J. \& Vanderpoorten, A. (2016a) Geographic range in liverworts: does sex really matter? Journal of Biogeography 43: 627-635. https://doi.org/10.1111/jbi.12661

Laenen, B., Machac, A., Gradstein, S.R., Shaw, B., Patiño, J., Désamoré, A., Goffinet, B., Cox, C.J., Shaw, A.J. \& Vanderpoorten, A. (2016b) Increased diversification rates correlate with bisexuality in liverworts. New Phytologist 210: 1121-1129. https://doi.org/10.1111/nph.13835

Liu, J., Zheng, S., Tiwari, R.M., Liu, L., Han, W. \& Liu, J. (2020) Similar mechanisms underlie beta diversity of bryophytes in two archipelagos with different isolation time. Ecosphere 11: e03296.

https://doi.org/10.1002/ecs2.3296

Liu, Y., Ah-Peng, C., Wilding, N., Bardat, J., Devos, N., Carter, B. \& Shaw, A.J. (2014) Population structure in the tropical peatmoss, Sphagnum tumidulum Besch. (Sphagnaceae). The Bryologist 117: 329-335.

https://doi.org/10.1639/0007-2745-117.4.329

Liu, Y., Medina, R., Devos, N., Vanderpoorten, A., Hedenäs, L., Bell, N.E., Shevock, J.R., Aguero, B., Quandt, D., Wickett, N.J., Shaw, A.J. \& Goffinet, B. (2019) The phylogeny of mosses: targeted sequencing of the organellar and nuclear genomes. Nature Communications 10: 1485 .

https://doi.org/10.1038/s41467-019-09454-w

Lloret, F. \& González-Mancebo, J.M. (2011) Altitudinal distribution patterns of bryophytes in the Canary Islands and vulnerability to climate change. Flora 206: 769-781. https://doi.org/10.1016/j.flora.2011.04.007

MacArthur, R.H. \& Wilson, E.O. (1963) An equilibrium theory of insular zoogeography. Evolution 17: 373-387. https://doi.org/10.1111/j.1558-5646.1963.tb03295.x

MacArthur, R.H. \& Wilson, E.O. (1967) The Theory of Island Biogeography. Princeton University Press, Princeton, N.J.

Marignani, M., Lussu, M., Murru, V., Bacaro, G. \& Cogoni, A. (2019) Effect of invasive alien species on the co-occurrence patterns of bryophytes and vascular plant species — the case of a Mediterranean disturbed sandy coast. Diversity 12: 160. https://doi.org/10.3390/d12040160

Marline, L., Ah-Peng, C. \& Hedderson, T.A.J. (2020) Epiphytic bryophyte diversity and range distributions along an elevational gradient in Marojejy, Madagascar. Biotropica 52: 616-626. https://doi.org/10.1111/btp.12781

Medina, R., Johnson, M.G., Liu, Y., Wickett, N.J., Shaw, A.J. \& Goffinet, B. (2019) Phylogenomic delineation of Physcomitrium (Bryophyta: Funariaceae) based on targeted sequencing of nuclear exons and their flanking regions rejects the retention of Physcomitrella, 
Physcomitridium and Aphanorrhegma. Journal of Systematics and Evolution 57: 404-417.

https://doi.org/10.1111/jse.12516

Miller, E.T., Farine, D.R. \& Trisos, C.H. (2017) Phylogenetic community structure metrics and null models: a review with new methods and software. Ecography 40: 461-477.

https://doi.org/10.1111/ecog.02070

Nogué, S., de Nascimento, L., Fernández-Palacios, J.M., Whittaker, R. \& Willis, K. (2013). The ancient forests of La Gomera, Canary Islands, and their sensitivity to environmental change. Journal of Ecology 101-377.

https://doi.org/10.1111/1365-2745.12051

Øien, D.-I., Pedersen, B., Kozub, L., Goldstein, K. \& Wilk, M. (2018) Long-term effects of nutrient enrichment controlling plant species and functional composition in a boreal rich fen. Journal of Vegetation Science 29: 907-920. https://doi.org/10.1111/jvs.12674

Patiño, J. \& Vanderpoorten, A. (2015) Macaronesia is a departure gate of anagenetic speciation in the moss genus Rhynchostegiella. Journal of Biogeography 42: 2122-2130. https://doi.org/10.1111/jbi.12583

Patiño, J. \& Vanderpoorten, A. (2018) Bryophyte biogeography. Critical Reviews in Plant Sciences 37: 175-209. https://doi.org/10.1080/07352689.2018.1482444

Patiño, J., Guilhaumon, F., Triantis, K.A., Gradstein, S.R., Hedenäs, L., González-Mancebo, J.M. \& Vanderpoorten, A. (2013a) Accounting for data heterogeneity in patterns of biodiversity: an application of Linear Mixed Models to the island biogeography of sporeproducing plants. Ecography 36 : 904-913. https://doi.org/10.1111/j.1600-0587.2012.00020.x

Patiño, J., Bisang, I., Hedenäs, L., Dirkse, G., Bjarnason, A.H., Ah-Peng, C. \& Vanderpoorten, A. (2013b) Baker's law and the island syndromes in bryophytes. Journal of Ecology 101: 1245-1255.

https://doi.org/10.1111/1365-2745.12136

Patiño, J., Medina, R., Vanderpoorten, A., Gonzaalez-Mancebo, J. M., Werner, O., Devos, N., Mateo, R. G., Lara, F. \& Ros, R.M. (2013c) Origin and fate of the single-island endemic moss Orthotrichum handiense. Journal of Biogeography 40: 857-868. https://doi.org/10.1111/jbi.12051

Patiño, J., Carine, M.A., Fernández-Palacios, J.M., Otto, R., Schaefer, H. \& Vanderpoorten, A. (2014a) The anagenetic world of sporeproducing land plants. New Phytologist 201: 305-311.

https://doi.org/10.1111/nph.12480

Patiño, J., Weigelt, P., Solymos, P., Guilhaumon, F., Kreft, H., Triantis, K., Naranjo, A. \& Vanderpoorten, A. (2014b) Differences in species-area relationships among the major lineages of land plants: a macroecological perspective. Global Ecology \& Biogeography 23: $1275-1283$.

https://doi.org/10.1111/geb.12230

Patiño, J., Solymos, P., Carine, M.A., Weigelt, P., Kreft, H. \& Vanderpoorten, A. (2015a) Island floras are not necessarily more speciespoor than continental ones. Journal of Biogeography 42: 8-15.

https://doi.org/10.1111/jbi.12422

Patiño, J., Carine, M., Mardulyn, P., Devos, N., Mateo, R.G., González-Mancebo, J.M., Shaw, A.J. \& Vanderpoorten, A. (2015b) Approximate Bayesian Computation reveals the crucial role of oceanic islands for the assembly of continental biodiversity. Systematic Biology 64: 579-589.

https://doi.org/10.1093/sysbio/syv013

Patiño, J., Zanatta, F., Mateo, R.G., Dirkse, G.M., Marquet, A., González-Mancebo, J.M., Sim-Sim, M., Gabriel, R., Aranda, S., Borges, P.A.V., Guisan, A. \& Vanderpoorten, A. (2016) Climate threat on the Macaronesian endemic bryophyte flora. Scientific Reports 6: 29156. https://doi.org/10.1038/srep29156

Patiño, J., Whittaker, R.J., Borges, P.A.V., Fernández-Palacios, J.M., Ah-Peng, C., Araújo, M.B., Ávila, S.P., Cardoso, P., Cornuault, J., de Boer, E.J., de Nascimento, L., Gil, A., González-Castro, A., Gruner, D.S., Heleno, R., Hortal, J., Illera, J.C., Kaiser-Bunbury, C.N., Matthews, T.J., Papadopoulou, A., Pettorelli, N., Price, J.P., Santos, A.M.C., Steinbauer, M.J., Triantis, K.A, Valente, L., Vargas, P., Weigelt, P. \& Emerson, B.C. (2017) A roadmap for island biology: 50 fundamental questions after 50 years of The Theory of Island Biogeography. Journal of Biogeography 44: 963-983.

https://doi.org/10.1111/jbi.12986

Patiño, J., Gómez-Rodríguez, C., Pupo-Correia, A., Sequeira, M. \& Vanderpoorten, A. (2018) Trees as habitat islands: temporal variation of alpha and beta diversity in epiphytic laurel forest bryophyte communities. Journal of Biogeography 45: 1727-1738. https://doi.org/10.1111/jbi.13359

Pisa, S., Vanderpoorten, A., Patiño, J., Werner, O., González-Mancebo, J.M \& Ros, R.M. (2015) How to define nativeness in vagile 
organisms: lessons from the cosmopolitan moss Bryum argenteum on the island of Tenerife (Canary Islands). Plant Biology 17: $1057-1065$.

https://doi.org/10.1111/plb.12348

Pócs, T. (2006) Bryophyte colonization and speciation on oceanic islands: an overview. Lindbergia 31: 54-62.

Pressel, S., Matcham, H.W., Supple, C. \& Duckett, J.G. (2017) Mosses, liverworts \& hornworts of Ascension Island. Pisces Publications, Newbury.

Rodrigues, A.S.B., Martins, A., Garcia, C.A., Sérgio, C., Porley, R., Fontinha, S., González-Mancebo, J.M., Gabriel, R., Phephu, N., Van Rooy, J., Dirkse, G., Long, D., Stech, M., Patinõ, J. \& Sim-Sim, M. (2020). Climate-driven vicariance and long-distance dispersal explain the Rand Flora pattern in the liverwort Exormotheca pustulosa (Marchantiophyta). Biological Journal of the Linnean Society 130: 480-496. https://doi.org/10.1093/biolinnean/blaa071

Saladin, B., Thuiller, W., Graham, C.H., Lavergne, S., Maiorano, L., Salamin, N. \& Zimmermann, N.E. (2019) Environment and evolutionary history shape phylogenetic turnover in European tetrapods. Nature Communications 10: 249. https://doi.org/10.1038/s41467-018-08232-4

Shaw, A.J., Cox, C.J. \& Goffinet, B. (2005) Global patterns of moss diversity: taxonomic and molecular inferences. Taxon 54: $337-352$. https://doi.org/10.2307/25065362

Silva, J.B., Sfair, J.C., Dos Santos, N.D. \& Pôrto, K.C. (2018) Bryophyte richness of soil islands on rocky outcrops is not driven by island size or habitat heterogeneity. Acta Botanica Brasilica 32: 161-168. https://doi.org/10.1590/0102-33062017abb0281

Silvertown, J., Francisco-Ortega, J. \& Carine M.A. (2005) The monophyly of island radiations: an evaluation of niche pre-emption and some alternative explanations. Journal of Ecology 93: 653-657. https://doi.org/10.1111/j.1365-2745.2005.01038.x

Sim-Sim, M., Ruas, S., Fontinha, S., Hedenäs, L., Sérgio, C. \& Lobo, C. (2014) Bryophyte conservation on a North Atlantic hotspot: Threatened bryophytes in Madeira and Selvagens Archipelagos (Portugal). Systematics and Biodiversity 12: 315-330. https://doi.org/10.1080/14772000.2014.918063

Sim-Sim, M., Lopes, T., Ruas, S. \& Stech, M. (2015) Does altitude shape molecular diversity and richness of bryophytes in madeira's natural forest? A case study with four bryophyte species at two altitudinal levels. Plant Ecology and Evolution 148: 171-180. https://doi.org/10.5091/plecevo.2015.1041

Söderström, L. (1992) Invasions and range expansions and contractions of bryophytes. In: Bates, J.W. \& Farmer, A.M. (Eds.) Bryophytes and lichens in a changing environment. Oxford Science Publications, Oxford, pp. 131-158.

Söderström, L. \& During, H.J. (2005) Bryophyte rarity viewed from the perspectives of life history strategy and metapopulation dynamics. Journal of Bryology 27: 261-268. https://doi.org/10.1179/174328205X70010

Söderström, L., Hagborg, A., von Konrat, M., Bartholomew-Began, S., Bell, D., Briscoe, L., Brown, E., Cargill, D.C., Costa, D.P., Crandall-Stotler, B.J., Cooper, E.D., Dauphin, G., Engel, J.J., Feldberg, K., Glenny, D., Gradstein, S.R., He, X., Heinrichs, J., Hentschel, J., Ilkiu-Borges, A.L., Katagiri, T., Konstantinova, N.A., Larraín, J., Long, D.G., Nebel, M., Pócs, T., Puche, F., ReinerDrehwald, E., Renner, M.A., Sass-Gyarmati, A., Schäfer-Verwimp, A., Moragues, J.G., Stotler, R.E., Sukkharak, P., Thiers, B.M., Uribe, J., Váňa, J., Villarreal, J.C., Wigginton, M., Zhang, L. \& Zhu, R.L. (2016) World checklist of hornworts and liverworts. Phytokeys 27: 1-828.

https://doi.org/10.3897/phytokeys.59.6261

Spitale, D. (2016) The interaction between elevational gradient and substratum reveals how bryophytes respond to the climate. Journal of Vegetation Science 27: 844-853.

https://doi.org/10.1111/jvs.12403

Stenøien, H.K., Hassel, K., Segreto, R., Gabriel, R., Karlin, E.F., Shaw, A.J. \& Flatberg, K.I. (2014) High morphological diversity in remote island populations of the peat moss Sphagnum palustre: glacial refugium, adaptive radiation or just plasticity? The Bryologist 117: $95-109$. https://doi.org/10.1639/0007-2745-117.2.095

Sundberg, S., Hansson, J. \& Rydin, H. (2006) Colonization of Sphagnum on land uplift islands in the Baltic Sea: Time, area, distance and life history. Journal of Biogeography 33: 1479-1491. https://doi.org/10.1111/j.1365-2699.2006.01520.x

Taylor, A. \& Burns, K. (2015) Epiphyte community development throughout tree ontogeny: An island ontogeny framework. Journal of Vegetation Science 26: 902-910. https://doi.org/10.1111/jvs.12289

Tiselius, A.K., Lundbäck, S., Lönnell, N., Jansson, R. \& Dynesius, M. (2019) Bryophyte community assembly on young land uplift 
islands-Dispersal and habitat filtering assessed using species traits. Journal of Biogeography 46: 2188-2202.

https://doi.org/10.1111/jbi.13652

Torre, G., Fernández-Lugo, S., Guarino, R. \& Fernández-Palacios, J.M. (2019) Network analysis by simulated annealing of taxa and islands of Macaronesia (North Atlantic Ocean). Ecography 42: 768-779.

https://doi.org/10.1111/ecog.03909

Vanderpoorten, A. \& Patiño, J. (2015) How to define nativeness in organisms with high dispersal capacities? A comment on Essl et al. Journal of Biogeography 42: 1360-1362.

https://doi.org/10.1111/jbi.12492

Vanderpoorten, A., Rumsey, F. \& Carine, M. (2007) Does Macaronesia exist? Conflicting signal in the bryophyte and pteridophyte floras. American Journal of Botany 94: 625-639.

https://doi.org/10.3732/ajb.94.4.625

Vanderpoorten, A., Devos, N., Hardy, O.J., Goffinet, B. \& Shaw, A.J. (2008) The barriers to oceanic island radiation in bryophytes: insights from the phylogeography of the moss Grimmia montana. Journal of Biogeography 35: 654-665.

https://doi.org/10.1111/j.1365-2699.2007.01802.x

Vanderpoorten, A., Laenen, B., Rumsey, F., Gonzalez-Mancebo, J.M., Gabriel, R. \& Carine, M.A. (2011) Dispersal, diversity and evolution of the Macaronesian cryptogamic floras. In: Bramwell, D. \& Caujapé-Castells (Eds.) The Biology of Island Floras. Cambridge University Press, Cambridge, pp. 338-364.

ttps://doi.org/10.1017/CBO9780511844270.015

Vanderpoorten, A., Patiño, J., Désamoré, A., Laenen, B., Gorski, P., Papp, B., Hola, E., Korpelainen, H. \& Hardy, O.J. (2019) To what extent are bryophytes efficient dispersers? Journal of Ecology 107: 2149-2154.

https://doi.org/10.1111/1365-2745.13161

Virtanen, R. (2014) Diaspore and shoot size as drivers of local, regional and global bryophyte distributions. Global Ecology and Biogeography 23: 610-619.

https://doi.org/10.1111/geb.12128

Wall, D.P. (2005) Origin and rapid diversification of a tropical moss. Evolution 59: 1413-1424. https://doi.org/10.1111/j.0014-3820.2005.tb01792.x

Weigelt, P., Jetz, W. \& Kreft, H. (2013) Bioclimatic and physical characterization of the world's islands. Proceedings of the National Academy of Sciences of the USA 110: 15307-15312. https://doi.org/10.1073/pnas.1306309110

White, O., Reyes-Betancort, J.A., Chapman, M. \& Carine, M.A. (2020) Geographical isolation, habitat shifts and hybridisation in the diversification of the Macaronesian endemic genus Argyranthemum (Asteraceae). New Phytologist 228: 1953-1971. https://doi.org/10.1111/nph.16980

Whittaker, R.J. \& Fernández-Palacios, J.M. (2007) Island Biogeography: Ecology, Evolution and Conservation, 2nd edn. Oxford University Press, Oxford.

Whittaker, R.J., Triantis, K.A. \& Ladle, R.J. (2008) A general dynamic theory of oceanic island biogeography. Journal of Biogeography 35: 977-994.

https://doi.org/10.1111/j.1365-2699.2008.01892.x

Yu, J., Shen, L., Li, D., \& Guo, S. (2019a) Determinants of bryophyte species richness on the Zhoushan Archipelago, China. Basic and Applied Ecology 37: 38-50.

https://doi.org/10.1016/j.baae.2019.05.002

Yu, J., Shen, L., Zang, C., Cai, J. \& Guo, S. (2019b) Geographical, anthropogenic and climatic determinants of bryophyte species composition and richness in the Shengsi archipelago, East China Sea. Journal of Bryology 41: 107-120. https://doi.org/10.1080/03736687.2019.1590673

Yu, J., Li, D., Zhang, Z. \& Guo, S. (2020) Species-area relationship and small-island effect of bryophytes on the Zhoushan Archipelago, China. Journal of Biogeography 47: 978-992.

https://doi.org/10.1111/jbi.13790

Zanatta, F., Engler, R., Collart, F., Broennimann, O., Mateo, R.G., Papp, B., Muñoz, J., Baurain, D., Guisan, A. \& Vanderpoorten, A. (2020) Bryophytes are predicted to lag behind future climate change despite their high dispersal capacities. Nature Communications 11: 5601 .

https://doi.org/10.1038/s41467-020-19410-8 